Kolyma, and he was thus enabled to obtain a glimpse of the shores of the Arctic Ocean. He accomplished the 500-mile journey in twelve days, in a frail open boat, made of very thin wooden planks sewn together with twisted willow-strands, the holes being plugged with moss and the cracks filled with the gum of the larch. Having reached Nijne-Kolymsk at the time of the fishing, he stayed there part of the summer and the winter, so that he could visit the lonely spot of Sukharnoye, as also some Chukchee encampments.

The pages given to the description of the Yukaghirs and the Yakutes settled along the lower course of the Kolyma, especially to the Chukchees, as also the legend about the disappearance of the small tribe of the Kangenici, will be read with deep interest and sympathy. All the little scenes sketched by the author bear the stamp of truthfulness and artistic feeling.

P. KROPOTKIN.

\section{WAR BREAD.}

THE public has been led to feel some anxiety concerning the effects of the present war bread upon national health and efficiency. Suggestion plays an inevitable part in such a connection. Certain untoward symptoms in individuals, for which some other tangible cause is not immediately evident, are liable just now to be ascribed on the slenderest evidence to the bread eaten. Once the belief in a deleterious influence has arisen, it is easy to understand how widely it may spread by suggestion. In the opinion of those best qualified to know, there would seem to be little basis for any such condemnation of the bread. It rests, nevertheless, with the Food Controller to obtain the best possible evidence concerning the facts, and we are glad to know that Lord Rhondda and the Wheat Commissioners have empowered a committee of the Royal Society to make a full and thorough investigation. This committee comprises some eminent medical consultants, as well as the physiologists who have been serving on the main Food Committee of the society. Its task is to decide whether the higher extraction of the grain can in itself be held responsible for any disturbance of health, and whether the admixture of other cereals with the wheat has produced a less digestible loaf, owing, for instance, to the associated difficulties in milling and baking.

Among other matters which are also engaging the attention of the committee is a greater tendency to "rope" in the bread, alleged to be due to the higher extraction of the grain. The habits of Bacillus mesentericus, which, in its various strains, is responsible for ropy bread, are already well known to bacteriologists, and, empirically at least, to all the better informed among practical bakers. There is no reason to doubt that with the increased knowledge now being acquired any outbreaks of rope will in the future be easily controlled. That the presence in the loaf of cereals other than wheat can be directly harmful is most unlikely. A favourable effect should indeed be seen in a somewhat improved balance in the protein supplied. Maize, it is true, is said to be badly tolerated by certain individuals, though such cases must be rare. It is also stated that the starch of maize is not fully gelatinised when it is cooked in admixture with wheat under conditions suitable for the production of an all-wheat loaf.

These and other points will doubtless receive the attention of the investigating committee. Its most important task, however, will be to decide, by a thorough sifting of the evidence, the more general question as to whether the war bread is, as a matter of fact, producing any ill effects at all upon the public health. The public will be glad to know that the Food Controller is in possession of the facts.

Meanwhile, since it is of the utmost importance to the nation that a full supply of bread shall be maintained, while the amount of wheat available is not sufficient for the purpose, we are glad to observe that the medical Press is urging the profession to see that the privilege of obtaining highgrade wheat flour for cases supposed to have suffered from the war bread is at any rate not abused.

\section{NOTES.}

Mr. Alan A. Campbell Swinton has been elected chairman of the council of the Royal Society of Arts for the ensuing year.

THE Asiatic Society of Bengal has awarded the Barclay memorial medal to Col. H. H. Godwin-Austen, for his work in biology. The medal is awarded every two years to the individual who during that period has made the most meritorious contribution to biology with special reference to India.

Dr. J. B. Cleland has been elected president of the Royal Society of New South Wales. After graduating in medicine, Dr. Cleland visited China and Japan, and later proceeded to this country, where he remained for several years, being for part of the time cancer research scholar at London Hospital. On returning to Australia, he was appointed Government pathologist and bacteriologist in Western Australia. In 1908 he became principal assistant microbiologist to the newly instituted Bureau of Microbiology in Sydney, and in I9I3, on the amalgamation of the bureau with the Department of Public Health, he was appointed principal microbiologist. $\mathrm{He}$ has also been associated with the experimental work of the Department of Agriculture.

REFERRING to Dr. Collinge's recent article on "The Destruction of House-sparrows" (NATURE, June 28, p. 347), Dr. W. A. Hollis writes to say that the assump. tion that the corn found in the stomachs of the adult birds has been taken from the fields is, he believes, an erroneous one, and that in nine cases out of ten it is obtained from horse-droppings, as the housesparrow rarely, if ever, goes far afield. At first sight this might appear so, but Dr. Hollis has overlooked the fact that the material upon which Dr. Collinge bases his argument was purposely obtained from agricultural districts, and in his account of the stomach contents of those birds obtained from suburban districts it is stated that the wheat was obtained "most likely from horse-droppings." The NO. 249I, VOL. 99] 